\title{
Effectiveness of the GAEC cross compliance standards Rational manage- ment of set aside, Grass strips to control soil erosion and Vegetation buffers along watercourses on surface animal diversity and biological quality of soil
}

\author{
Marta Biaggini, ${ }^{1}$ Paolo Bazzoffi, ${ }^{2}$ Roberta Gentile, ${ }^{3}$ Claudia Corti ${ }^{1}$ \\ 1 Museo di Storia Naturale dell'Università degli Studi di Firenze, Sezione di Zoologia "La Specola", \\ Firenze; ${ }^{2}$ CRA-ABP Agricultural Research Council, Agrobiology and Pedology Research Centre, \\ Firenze; ${ }^{3}$ Research Fellow, CRA-ABP Agricultural Research Council, Agrobiology and Pedology \\ Research Centre, Firenze, Italy
}

\begin{abstract}
Landscape simplification and loss of natural and semi-natural habitats are the major causes of biodiversity decrease in agricultural landscapes. In order to mitigate the effects of intensive agricultural management the Ministry of Agricultural, Food and Forestry Policies in Italy has included the agronomic measures Rational management of set aside, Grass strips to control soil erosion and Vegetation buffers along watercourses in the decree on cross compliance. In this paper we review the results of a field research performed in Central Italy. The aim of the study was to evaluate the efficacy of the above mentioned GAEC standards for animal diversity enhancement. Using different animal groups as indicators, superficial arthropod fauna and herpetofauna, we found striking differences in the biodiversity levels of areas characterized by the application or by the lack of GAEC standards, with the latter being characterized by a significatively impoverished fauna. In particular, the set aside area and the buffer of riparian vegetation resulted of primary importance to allow higher biodiversity levels. Also the analysis of the biological quality of the soil, as assessed through the QBS-ar index based on edaphic micro-Arthropod fauna, indicated a higher quality of semi-natural habitats with respect to arable lands.
\end{abstract}

Correspondence: Marta Biaggini, Museo di Storia Naturale dell'Università degli Studi di Firenze, Sez. di Zoologia "La Specola", via Romana 17, 50125 Firenze, Italy.

E-mail: marta.biaggini@virgilio.it

Key words: agriculture, arthropods, biodiversity, herpetofauna, indicators, GAEC, cross compliance.

Received for publication: 19 April 2011.

Accepted for publication: 20 April 2011

(C) Copyright M. Biaggini et al., 2011

Under no circumstances figures can be used without prior written consent of the copyright owner.

Licensee PAGEPress, Italy

Italian Journal of Agronomy 2011; 6(s1):e14

doi:10.4081/ija.2011.6.s1.e14

This work is licensed under a Creative Commons Attribution NonCommercial 3.0 License (CC BY-NC 3.0).

\section{Introduction}

The intensification of farming systems occurred in Western Europe from the $20^{\text {th }}$ century had caused a deep transformation of the agricultural landscapes, with particular reference to the arable lands (Nentwig, 2003). The traditional agricultural landscape made up of a mosaic of natural, semi-natural and agricultural habitats, has been replaced by a more artificial environment characterized by the huge expansion of cultivated plots and the consequent loss of most undisturbed habitats (Wilcove et al., 1986; Andrén, 1994; Maisonneuve and Rioux, 2001). Such process, along with the development of large-scale production practices, had led to a general simplification of the rural landscape and, as a consequence, to a consistent loss of biodiversity (Meeus et al., 1990; Burel et al., 1998; Zechmeister and Moser, 2001; Moser et al., 2002). Indeed, in agricultural environment, as well as in most of terrestrial ecosystems, loss of biodiversity is closely related to habitat fragmentation and habitat loss (Shaffer, 1987; Wilson, 1988; Kremen et al., 1993; Blaustein et al., 1994; Gibbons and Stangel, 1999; Collinge, 2000; Gibbons et al., 2000; Kuussaari et al., 2000; Hunter, 2002).

In 2010 a new vision and target on biodiversity at European and global level for the post 2010 period have been adopted by the EU at the tenth Conference of the Parties to the Convention on Biological Diversity. The new vision is: By 2050 European Union biodiversity and the ecosystem services it provides - its natural capital - are protected, valued and appropriately restored for biodiversity's intrinsic value and for their essential contribution to human wellbeing and economic prosperity, and so that catastrophic changes caused by the loss of biodiversity are avoided. The new target is: Halting the loss of biodiversity and the degradation of ecosystem services in the EU by 2020, and restoring them in so far as feasible, while stepping up the EU contribution to averting global biodiversity loss. (http:/www.eea.europa. eu/themes/biodiversity).

In such vision and target, the protection of the remaining natural and semi-natural patches become of primary importance for conservation purposes in agricultural landscapes (Greaves and Marshall, 1987; Duelli and Obrist, 2003; Pfiffner and Luka, 2003; Woodcock et al., 2005). Indeed, the enhancement of environmental diversification obtained by the maintenance or the increase of semi-natural habitats, such as buffer strips, ecotones (vegetated borders, grass strips), and set aside areas can represent an effective measure for fauna conservation in intensively exploited areas (Asteraki et al., 1995; Kromp and Steinberger, 1992; Andersen, 1997; Maisonneuve and Rioux, 2001; Hunter, 2002).

GAECs (Standards of Good Agricultural and Environmental Condition) form part of the requirements under cross compliance and 
apply to anyone who receives payments under the Single Payment Scheme. GAECs set requirements for farmers in respect of soils, as well as maintaining a range of habitat and landscape features which are characteristic of the Italian countryside. The standards Rational management of set aside, Grass strips to control soil erosion and Vegetation buffers along watercourses concern the environmental objective to Ensure a minimum level of maintenance and avoid the deterioration of habitats indicated in Annex IV of REG. EC 1782/03. The first two standards were introduced by successive Mipaaf (Ministry of Agricultural, Food and Forestry Policies) decrees on cross compliance from mid-2004 (Decree 1787/2004 et seq.) until the end of 2009. The standard vegetation buffers along watercourse have been introduced by the Decree of 2009 issued following the CAP Health Check. ${ }^{1}$

In this review paper, realized in the context of the EFFICOND project, we present in an overall perspective the results of a field research aimed at investigating and comparing animal diversity levels in agricultural areas in which GAEC standards were applied and in cultivated areas in which these standards were not applied. We considered different animal groups, most of which typically used as bio-indicators, and we compared their diversity levels among habitats characterized by varying management intensity and vegetation cover. Specifically, we surveyed superficial Arthropods, edaphic micro-Arthropods, and Amphibians and Reptiles among the vertebrates (Paggetti et al., 2006; Biaggini et al., 2006, 2007; data on edaphic micro-arthropod fauna and evaluation of soil biological quality are introduced in this paper).

\section{Materials and Methods}

\section{Study sites}

The study was performed in Tuscany, Central Italy, in an agricultural area, the Valdera region, mainly characterized by intensively cultivation of cereals. In this area we surveyed eight sites, including cultivated plots, natural and semi-natural habitats (Table 1).

The surveyed sites were the following:

- intensively cultivated wheat field (F);

- woodlot (W) formed by an oak coppice, with trees reaching the height of 8-10 m. The underwood is mainly made by butcher's broom and thorn-bush;

- pasture (P) used for sheep grazing

- grass strips (GS): inserted in an organically cultivated area. The strips are overgrown with a continuous cover of herbaceous vegetation, growing up to $50 \mathrm{~cm}$ in spring;

- cultivated strips (CS): alternated with the grass covered strips, they are devoted to organic farming of cereals;

- set aside area (SA): an uncultivated meadow situated close to the strips (GS and CS) and a shrubby lot. The prevalent essence is couch grass;

- vegetation buffer strip (BS): a riparian strip along the ditch botro Cavalcanti, with banks overgrown with a thick vegetation (herbaceous species and bramble bushes) which hides the ditch-bed. The ditch-bed is less than $1 \mathrm{~m}$ wide and it dries out during summer.

Finally, one more site was investigated for the evaluation of soil biological quality:

- A shrubby lot (S): natural shrub vegetation composed prevalently by Prunus spinosa, Crataegus oxyacantha, Fraxinus sp.

- GS, CS, SA, BS and S were located inside theCRA-ABP experimental farm in Vicarello.

${ }^{1}$ On 20 November 2008 the EU agriculture ministers reached a political agreement on the Health Check of the Common Agricultural Policy (CAP). The Health check introduced a number of changes to the EU rules for the Single Payment Scheme (SPS) and other direct aid schemes.

\section{Sampling procedures}

\section{Edaphic micro-Arthropods}

Edaphic micro-arthropod fauna was sampled in order to obtain an estimation of the Soil Biological Quality index QBS-ar (Parisi, 2001) in the eight surveyed sites (Table 1). Such index is a simplified eco-morphological index based on a general evaluation of soil micro-arthropod community that does not require the classification of organisms at specific level. It is based on the biological form approach (Sacchi and Testard, 1971), following the concept that the higher the soil quality is, the higher will be the number of micro-arthropod groups well adapted to the soil habitats (Parisi et al., 2005).

For each site we collected three soil samples of $10 \times 10 \times 10 \mathrm{~cm}$ (for a total of 24 soil samples) during every sampling day. Sampling was repeated every two months, from July 2003 to June 2004. Soil sample collection and micro-Arthropod extraction were performed following the standard methodologies usually applied in soil biology and recommended for QBS-ar application (Phillipson, 1971; Parisi, 2001; Parisi et al., 2005). Soil samples were transported to the laboratory of the Agrobiology and Pedology Research Centre (CRA-ABP Agricultural Research Council, Florence) where we extracted micro-organisms using the modified Berlese-Tullgren funnel (Wallwork, 1976; Parisi, 2001; André et al., 2002; Parisi et al., 2005). The determination of biological forms and the calculation of QBS index followed the standard methodologies (Parisi, 2001; D’Avino, 2002; Parisi et al., 2005).

\section{Superficial Arthropods}

Superficial arthropod fauna was sampled using pitfall traps. We placed a total of 34 pitfall traps in seven different sites; in each surveyed site we put traps in grids of about $30 \times 10 \mathrm{~m}$ (Table 1). Each trap consisted of a plastic tank (diameter $=8 \mathrm{~cm} ; \mathrm{h}=10 \mathrm{~cm}$ ) filled with a solution of vinegar (attractive function) and acetylsalicylic acid (with preservative function); every tank was buried in the ground so that its border was just at the ground level. A non-transparent plastic cover was placed $10 \mathrm{~cm}$ above each trap to prevent flooding from rainwater and evaporation of the inside solution. Traps were emptied and replaced once every 14 days from May 2003 to May 2004. In this paper we focus on Arthropods identified at the taxonomic level "Order". For more details see Biaggini et al. (2007).

\section{Herpetofauna}

Data on Amphibians and Reptiles derive from animals occasionally fallen into the pitfall traps set for arthropod fauna sampling and into 15 water tanks located inside SA, in the experimental area, and used for rainfall, runoff and sediment sampling. Observations of free ranging animals were also performed.

\section{Statistical analyses}

\section{Edaphic micro-arthropods}

In order to compare QBS-ar values among habitats with different vegetation cover features we grouped the surveyed sites into three main categories: i) arable lands, grouping $\mathrm{F}$ and $\mathrm{CS}$; ii) meadows, grouping GS, P, and SA; iii) woody habitats, grouping $\mathrm{W}$ and $\mathrm{S}$. For each of these habitat categories we calculated the mean values of QBS-ar in the six sampling dates. Then we compared such means among habitat categories by a randomized One-Way Anova, using Resampling Procedures 1.3 software. Finally, we searched for differences among pairs using a randomized U-test; Bonferroni correction was applied for multiple comparisons.

\section{Superficial Arthropods}

Fauna composition of superficial arthropod orders was analyzed 
using multidimensional scaling, as indicated in Biaggini et al., 2007. To assess biodiversity levels in the surveyed sites, for each pitfall trap we calculated the Shannon-Wiener index (Shannon and Weaver, 1948) considering the total specimens collected in the whole year of sampling activity. In order to test for differences among sites, we compared these values using ANOVA analysis. Tukey HSD post-hoc comparisons were applied.

\section{Herpetofauna}

We analyzed data derived from individuals occasionally fallen into pitfall traps. In particular, we focused on lacertid lizards because they were most of the collected individuals, and they were present in six out of the seven surveyed sites. Additionally, they can be considered reliable and useful indicators in Mediterranean agro-ecosystems (Biaggini et al., 2009; Paggetti et al., 2006; Corti and Lebborni, 2004). We compared the number of lizards among sites using Kruskall-Wallis test; we also compared the number of individuals collected in the intensive wheat field (F) and in the cultivated area inside the experimental farm (considering GS+CS) using a Mann-Whitney U-test (see Biaggini et al., 2006 for more details).

\section{GIS application}

We present a possible application of the Geographic Information System (GIS) by extending the values of animal diversity and soil biological quality recorded in the field to the surroundings of the study area characterized by similar land uses. Photo interpretation of land use was based on aerial photos AIMA 1:2000. Maps were produced using ArcView 3.2 GIS.

\section{Results}

\section{Edaphic micro-Arthropods}

Final QBS-ar values of each site and habitat category are reported in Table 1, while the trend of the index during the year is represented in
Figure 1. Anova analysis showed significant differences of QBS-ar values among the three habitat categories we defined $(\mathrm{F}=22.353$; $\mathrm{P}<0.001)$. Specifically, randomized U-test, after the application of Bonferroni correction $(\mathrm{P}=0.05 / 2=0.025)$, revealed a significant difference of QBS-ar values between woody habitats and arable lands $(\mathrm{t}=-$ $6.541, \mathrm{P}=0.0016)$, and between woody habitats and meadows $(\mathrm{t}=-4.863$, $\mathrm{P}=0.0017)$, but not between meadows and arable lands $(\mathrm{t}=-2.379$, $\mathrm{P}=0.0411$ n.s.) (Figure 2).

\section{Superficial Arthropods}

We identified 26 orders of Arthropods among which Collembola, Diptera, Coleoptera and Hymenoptera represented 53.8\%, 15.4\%, 14.0\% and $5.0 \%$ of the collected specimens, respectively. MDS performed on the frequencies of arthropod orders revealed that W, P, and F traps clustered into three separate groups, while the traps belonging to the other sites grouped together, in the same cluster (Biaggini et al., 2007; Figure 3). ANOVA analysis performed on Shannon-Wiener index values, considering the total specimens collected, revealed significant dif-

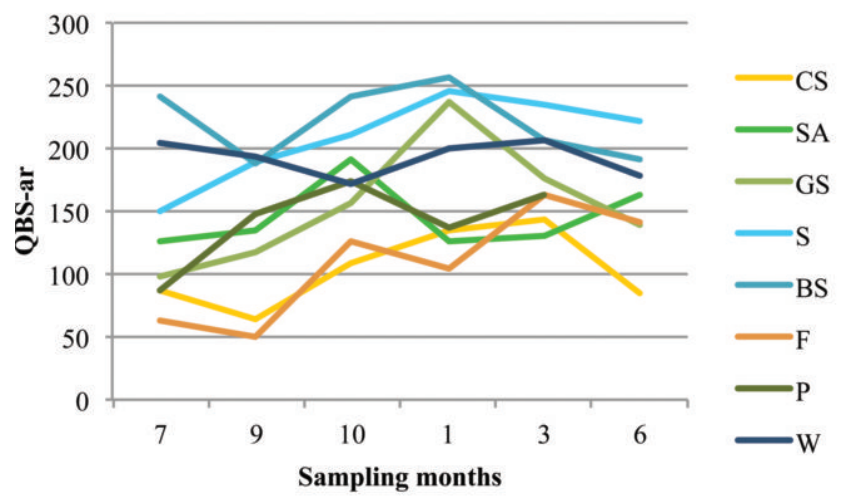

Figure 1. QBS-ar values during the year of sampling activity in the surveyed sites.

Table 1. Abbreviations, environmental features and main results regarding superficial Arthropod diversity (Shannon-Wiener index values, $\mathrm{H}$, means $\pm \mathrm{SD}$ ), number of species of Amphibians and Reptiles collected and observed, and QBS-ar values (means \pm SD ) of the surveyed sites. Number of pitfall traps and collected soil samples are also reported for each site (from Biaggini et al., 2007 modified).

\begin{tabular}{|c|c|c|c|c|c|c|c|c|c|}
\hline Sites & & Size (m) & $\begin{array}{l}\text { Management and } \\
\text { main vegetation } \\
\text { features }\end{array}$ & $\begin{array}{l}N \text { of pitfall } \\
\text { traps }\end{array}$ & $\begin{array}{l}\mathrm{N} \text { of soil } \\
\text { samples }\end{array}$ & H & $\begin{array}{l}\text { N of herp. } \\
\text { species }\end{array}$ & $\begin{array}{l}\text { QBS-ar } \\
\text { sites }\end{array}$ & $\begin{array}{l}\text { QBS-ar } \\
\text { habitat } \\
\text { categories }\end{array}$ \\
\hline $\begin{array}{l}\text { Cultivated } \\
\text { strips }\end{array}$ & $\mathrm{CS}$ & $17 \times 60$ each & $\begin{array}{l}\text { Organically cultivated wheat } \\
\text { (Triticum turgidum L. var. durum) }\end{array}$ & $\begin{array}{l}4 \\
\text { (into different strips) }\end{array}$ & 3 & $2.37 \pm 0.11$ & 5 & $103.5 \pm 31.30$ & $105.92 \pm 36.57$ \\
\hline Field & $\mathrm{F}$ & $150 \times 80$ & $\begin{array}{l}\text { Intensively cultivated wheat } \\
\text { (Triticum turgidum L. var. durum) }\end{array}$ & 6 & 3 & $1.18 \pm 0.26$ & 1 & $108.33 \pm 44.14$ & \\
\hline $\begin{array}{l}\text { Grass } \\
\text { strips }\end{array}$ & GS & $4.40 \times 60$ each & $\begin{array}{l}\text { Undisturbed thick mantle } \\
\text { of herbaceous species. } \\
\text { Prevalence of: Medicago spp., } \\
\text { Bromus spp.,Avena spp., Poa spp. }\end{array}$ & $\begin{array}{l}4 \\
\text { (into different strips) }\end{array}$ & 3 & $2.64 \pm 0.06$ & 1 & $154.67 \pm 49.44$ & \\
\hline $\begin{array}{l}\text { Set } \\
\text { aside area }\end{array}$ & SA & $15 \times 90$ & $\begin{array}{l}\text { Uncultivated meadow. } \\
\text { Prevalent essences: } \\
\text { Bromus spp., Avena spp., Poa spp. }\end{array}$ & 8 & 3 & $2.53 \pm 0.11$ & 11 & $145.17 \pm 26.10$ & $149.92 \pm 35.95$ \\
\hline Pasture & $\mathrm{P}$ & $60 \times 70$ & $\begin{array}{l}\text { Sheep grazing. Main essences: } \\
\text { Medicago spp., Trifolium spp. }\end{array}$ & 4 & 3 & $1.95 \pm 0.22$ & 1 & $141.4 \pm 33.65$ & \\
\hline Buffer strip & BS & 1-2m wide & $\begin{array}{l}\text { Riparian strip with prevalence } \\
\text { of Rubus spp. and Arundo spp. }\end{array}$ & 4 & 3 & $2.46 \pm 0.19$ & 7 & $221.33 \pm 29.34$ & \\
\hline $\begin{array}{l}\text { Woodlot } \\
\text { Shrubby lot }\end{array}$ & $\begin{array}{l}\text { W } \\
\text { S }\end{array}$ & $\begin{array}{l}70 \times 120 \\
50 \times 125\end{array}$ & $\begin{array}{l}\text { Quercus spp. wood used for silviculture } \\
\text { Natural shrubs with prevalence of } \\
\text { Prunus spp., Crataegus spp., } \\
\text { and Fraxinus spp. }\end{array}$ & 4 & 3 & $2.46 \pm 0.08$ & 3 & $192.17 \pm 14.55$ & $207.5 \pm 28.69$ \\
\hline
\end{tabular}


ferences among sites $(\mathrm{F}=53.595, \mathrm{P}<0.001)$ (Figure 4). Specifically, $\mathrm{F}$ and $\mathrm{P}$ were characterized by biodiversity levels significantly lower than all the other sites, as shown by Tukey HSD post-hoc comparisons (Figure 4, Table 2).

\section{Herpetofauna}

We collected and observed a total of eleven species of Amphibians and Reptiles, distributed in the surveyed sites as indicated in Table 3 and Figure 5. In particular we recorded two newt species (Lissotriton vulgaris, Triturus carnifex), two toad species (Bufo bufo, B. viridis) and one green frog species (Pelophylax klepton esculenta), three lacertid species (Lacerta bilineata, Podarcis muralis, P. siculus), one skink (Chalcides chalcides) and two snake species (Hierophis viridiflavus, Vipera aspis). Kruskall-Wallis test performed on lacertid lizard abundance revealed significant differences among the investigated sites $\left(\chi^{2}=17.33\right.$, Monte Carlo sig. $\mathrm{P}=0.001$ ) (Figure 6); post-hoc comparisons highlighted a significant difference between GS and F; the comparison between the two agricultural managements showed that the experimental cultivated area hosted a significantly higher number of lacertids if compared to the intensively managed one (GS+CS $v s \mathrm{~F}, \mathrm{n} 1=8, \mathrm{n} 2=6$, Mann Whitney test: $\mathrm{U}=9.000$, Monte Carlo sig. $\mathrm{P}=0.047$ ) (Figure 6).

\section{Discussion}

Loss and habitat fragmentation are considered among the major threats for biodiversity. Their effects are particularly marked in high input agricultural systems where the intensification of agricultural practices have brought to a general loss of the original habitats and of and many of their inhabitants (Burel et al., 1998; Zechmeister and Moser, 2001; Moser et al., 2002; Duelli and Obrist, 2003). The loss of many uncultivated elements, typical of traditional agricultural landscapes, such as woodlots, hedgerows and riparian strips of vegetation, removed to enlarge exploited areas and facilitate cultivation, has contributed to a general impoverishment of agricultural environment, too (Burel et al., 1998). Indeed, these processes have lead most often to landscape simplification and consequent decreasing species richness (Meeus et al., 1990; Zechmeister and Moser, 2001; Moser et al., 2002).

The importance of these semi-natural habitats for the enhancement of biodiversity in agricultural environments is clearly supported by our results. Taking into account different animal groups, we observed that areas in which relatively undisturbed habitats are present, host more species than intensively exploited ones. Intriguingly, we found noticeable differences in the biodiversity levels of different land uses, even if working at field scale and considering relatively small sites.

The analyses performed on superficial arthropod fauna revealed an interesting variability among sites in both fauna diversity and composition. Specifically, we found that the most intensively exploited sites, $\mathrm{P}$ and $\mathrm{F}$, characterized by big surfaces and lack of GAEC standard appli-

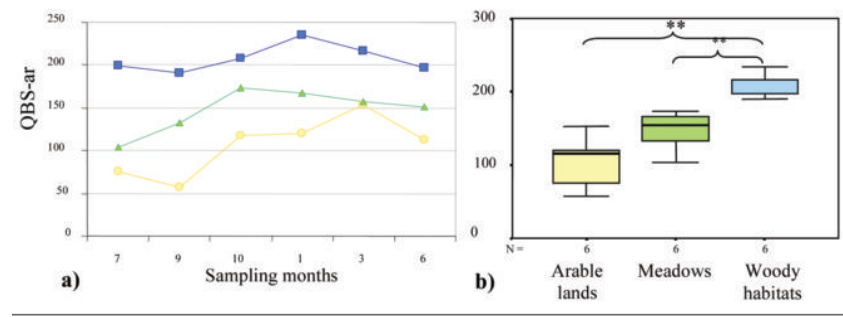

Figure 2. QBS-ar mean values in arable lands (yellow), meadows (green) and woody habitats (blue) during the whole year of sampling activity (a); and Anova comparison of such values with randomization tests $(b)$.

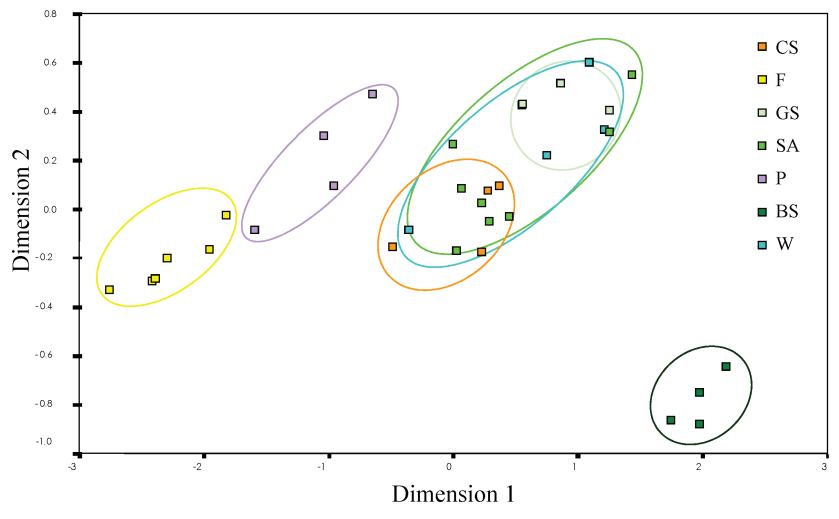

Figure 3. Multidimensional scaling performed on the frequencies of Arthropod orders considering the whole sampling period. (from Biaggini et al., 2007 modified).

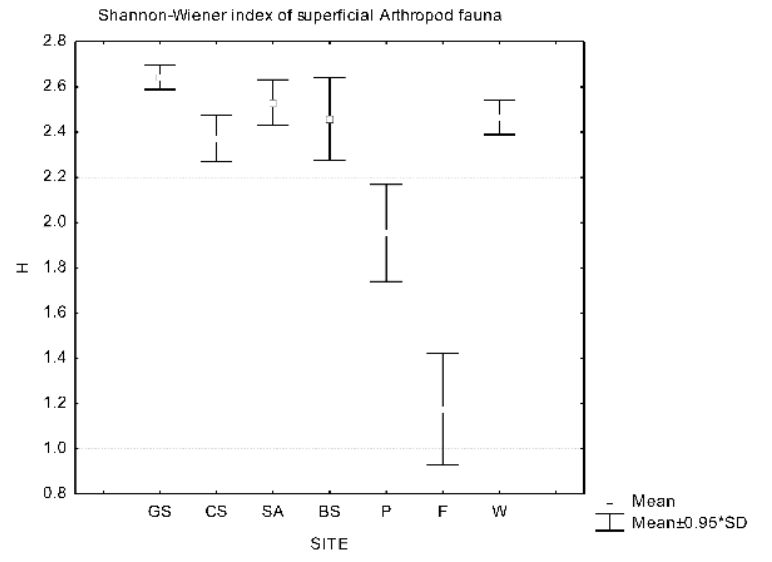

Figure 4. Mean values $( \pm \mathrm{SD})$ of Shannon-Wiener index, calculatedthe total specimens collected in the surveyed sites.

Table 2. P-values of Tukey HSD post-hoc comparisons among different sites of the Shannon-Wiener index values calculated on superficial arthropod fauna.

\begin{tabular}{lccccccc} 
Sites & CS & GS & SA & BS & P & F & W \\
CS & - & 0.281564 & 0.705567 & 0.989939 & 0.020400 & 0.000136 & 0.984419 \\
GS & 0.281564 & - & 0.925893 & 0.699018 & 0.000180 & 0.000136 & 0.736320 \\
\hline SA & 0.705567 & 0.925893 & - & 0.989557 & 0.000216 & 0.000136 & 0.994064 \\
BS & 0.989939 & 0.699018 & 0.989557 & - & 0.003479 & 0.000136 & 1.000000 \\
\hline P & 0.020400 & 0.000180 & 0.000216 & 0.003479 & - & 0.000137 & 0.002976 \\
F & 0.000136 & 0.000136 & 0.000136 & 0.000136 & 0.000137 & - & 0.000136 \\
\hline W & 0.984419 & 0.736320 & 0.994064 & 1.000000 & 0.002976 & 0.000136 & - \\
\hline
\end{tabular}

CS, cultivated strips; F, field; GS, grass strips; SA, set aside; P, pasture; BS, buffer strip; W, woodlot; S, shrubby lot. 
Table 3. Amphibian and reptile species recorded in the study sites. Data on presence-absence of herpetofauna species derive from field observations and from animals occasionally fallen into the pitfall traps.

\begin{tabular}{|c|c|c|c|c|c|c|c|c|c|c|c|}
\hline Site & $\begin{array}{l}\text { Triturus } \\
\text { carnifex }\end{array}$ & $\begin{array}{c}\text { Lissotriton } \\
\text { vulgaris }\end{array}$ & $\begin{array}{l}\text { Bufo } \\
\text { bufo }\end{array}$ & $\begin{array}{c}\text { Amy } \\
\text { Bufo } \\
\text { viridis }\end{array}$ & $\begin{array}{l}\text { hibian and r } \\
\text { Pelophylax } \\
\text { klepton } \\
\text { esculenta }\end{array}$ & $\begin{array}{c}\text { ptile specie } \\
\text { Podarcis } \\
\text { siculus }\end{array}$ & $\begin{array}{l}\text { Podarcis } \\
\text { muralis }\end{array}$ & $\begin{array}{l}\text { Lacerta } \\
\text { bilineata }\end{array}$ & $\begin{array}{l}\text { Chalcides } \\
\text { chalcides }\end{array}$ & $\begin{array}{l}\text { Coluber } \\
\text { viridiflavus }\end{array}$ & $\begin{array}{c}\text { Vipera } \\
\text { aspis }\end{array}$ \\
\hline CS & $X$ & - & - & - & - & $X$ & X & - & $X$ & $X$ & - \\
\hline GS & - & - & - & - & - & $X$ & - & - & - & - & - \\
\hline SA & $X$ & $X$ & $X$ & $X$ & $X$ & $X$ & $X$ & $X$ & $X$ & $X$ & $X$ \\
\hline BS & $X$ & $X$ & - & - & $X$ & $X$ & X & $X$ & - & $X$ & - \\
\hline W & - & - & $X$ & - & - & $X$ & $X$ & - & - & - & - \\
\hline $\mathrm{F}$ & - & - & - & - & - & - & $X$ & - & - & - & - \\
\hline$P$ & $X$ & - & - & - & - & - & - & - & - & - & - \\
\hline
\end{tabular}

cation, clearly show very low biodiversity levels if compared to seminatural habitats and to the cultivated strips inside the experimental farm. Also the analysis of fauna composition highlighted strong differences among these two land uses, $\mathrm{P}$ and $\mathrm{F}$, and all the other sites. As a matter of facts, $\mathrm{P}$ and $\mathrm{F}$ superficial arthropod fauna composition is clearly distinguishable from the one collected elsewhere, including the cultivated strips and the set aside area in the experimental farm. The only further site whose fauna composition visibly differentiates from the others is the woodlot, that is a habitat with unique vegetation features.

Interestingly, data on herpetofauna clearly support the thesis that landscape diversification enhances animal diversity levels, too. Indeed, inside the CRA-ABP experimental farm we sampled not only a higher number of individuals but also a higher number of species. In this area we collected and observed a total of five species of Amphibians and six species of Reptiles while the intensively managed wheat field hosted just one lizard species (Podarcis muralis). Interestingly, lizards in the wheat field were collected and observed exclusively next to the vegetated edge (a thin strip of bramble bushes) and never in the core of the cultivated area. These observations indicate that the presence of buffer zones and ecotones can greatly enhance species richness in agricultural landscapes (Bastian et al., 2007). Our results appear even more meaningful if considering that the experimental farm is a quite small area (we surveyed a surface of about $30,600 \mathrm{~m}^{2}$ ), located in a highly exploited environment, dominated by huge extensions of intensively managed cereal fields. Nonetheless, as seen, this area clearly represents an important refuge for Vertebrates like Amphibians and Reptiles. The analyses focused on lacertid lizard species, confirm that even the cultivated area inside the experimental farm is richer in individuals than the intensively exploited area where GAEC standards were not applied. Even if further and more extensive investigations should be performed to corroborate our findings, other studies suggest that open areas, subjected to a moderate exploitation such as traditional forms of agriculture, can favor the presence of some reptiles (McNeely 1995; La Mantia 1997; Hódar et al. 2000; Germaine and Wakeling 2001; Smart et al. 2005; Graziani et al., 2006). As such, our data could represent useful evidences to support the maintenance or creation of set aside and buffer zones as an effective measure to mitigate the environmental exploitation due to intensive agricultural practices. Specifically, our observations indicate that the set aside area and the buffer strip of riparian vegetation are habitats of primary importance for herpetofauna (Table 3).

Finally, in accordance with other studies, the biological quality of the soil, as assessed by using the QBS-ar index, showed an increasing trend from arable lands, to grassland and woody habitats (Gardi et al., 2003). Such trend could suggest a possible negative correlation between the biological quality of the soil and anthropic pressure (Gardi

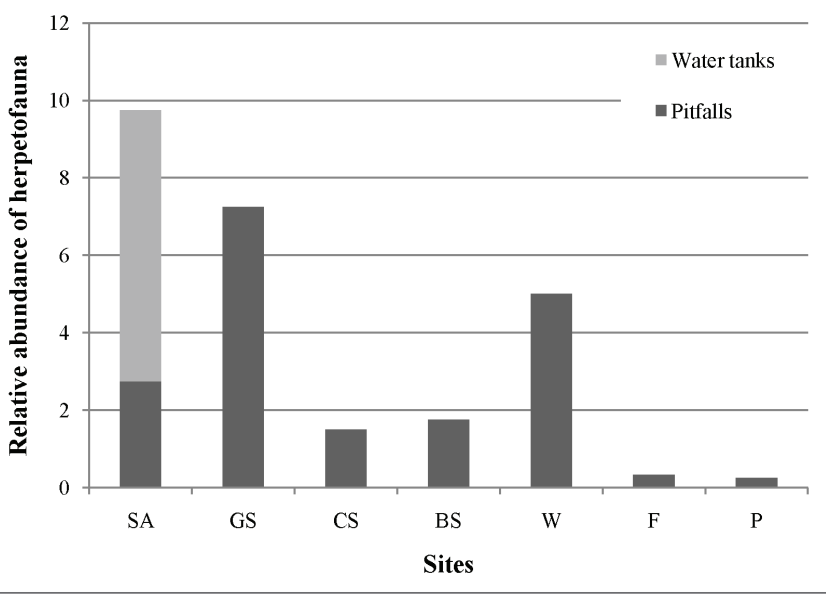

Figure 5. Relative abundance of Amphibians and Reptiles occasionally fallen into pitfall traps (and water tanks) in the different sites ( $\mathrm{N}$ of specimens/ $\mathrm{N}$ of traps or tanks is represented).
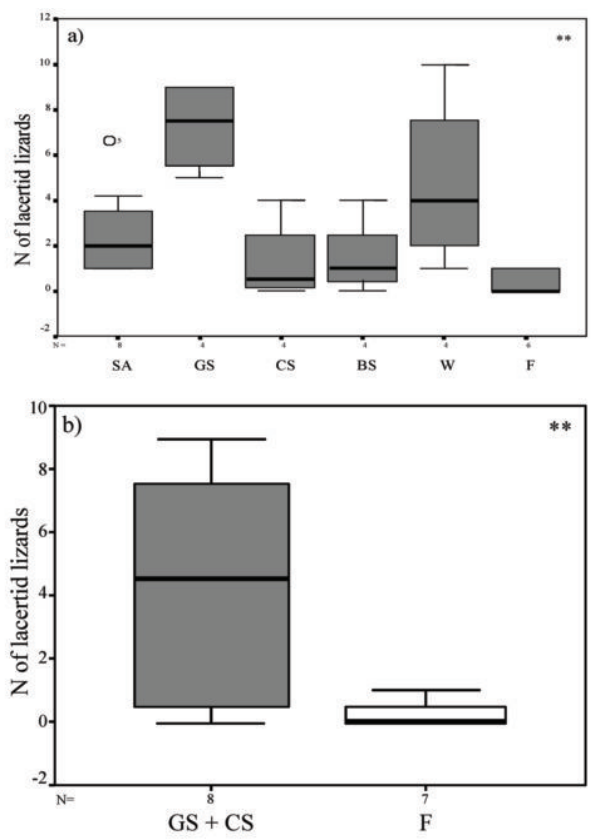

Figure 6. Abundance of lacertid lizards in the surveyed sites (a); and comparison between the intensive wheat field $(F)$ and the cultivated area inside the experimental farm (considering GS+CS) (b) (from Biaggini et al., 2006, modified). 

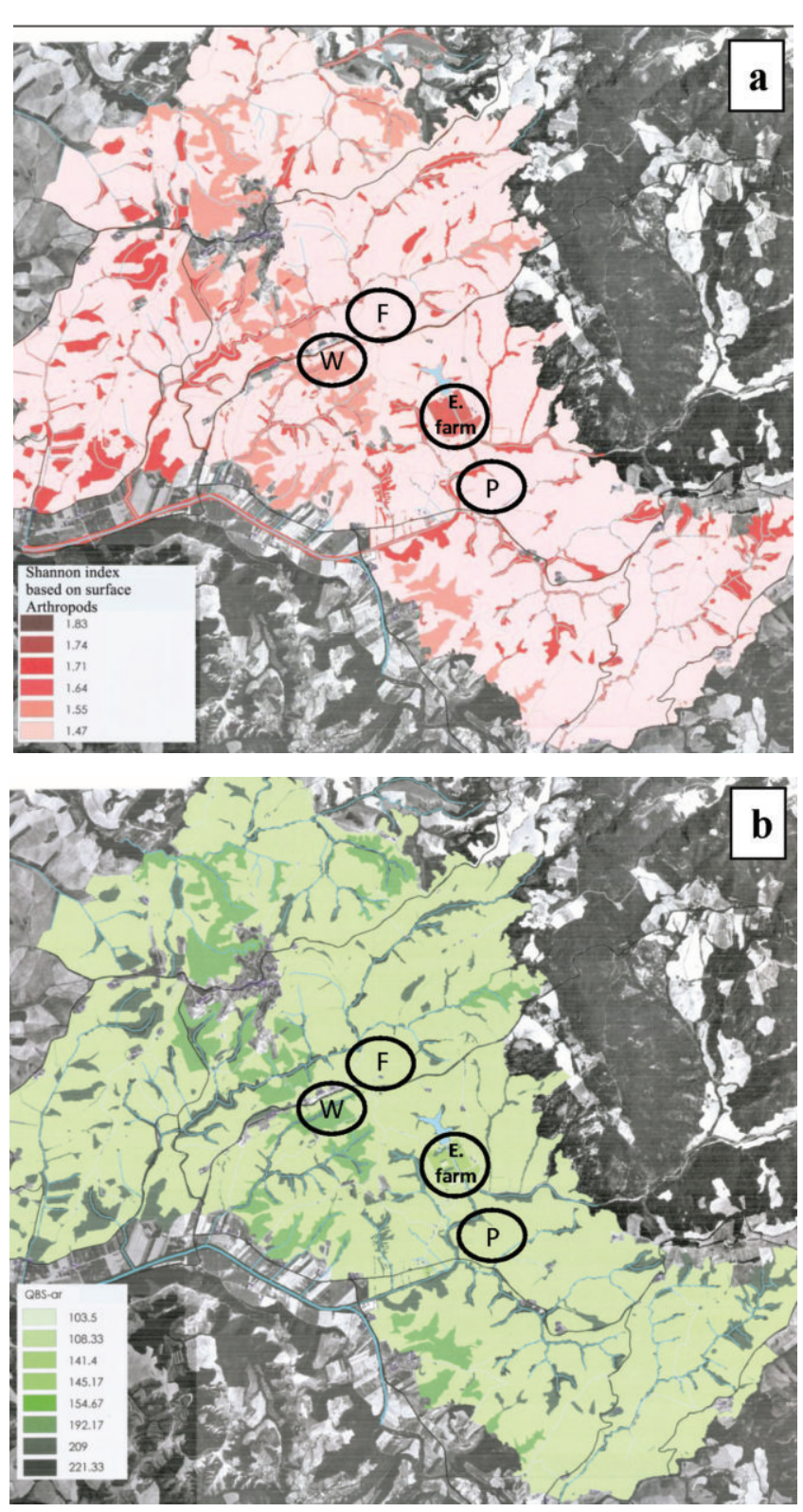

Figure 7. Extrapolation of the arthropod fauna Shannon-Wiener index (a) and QBS-ar index (b) in an area of $37.14 \mathrm{~km}^{2}$ surrounding the study sites (F, W, P, experimental farm) and characterized by similar agricultural land uses.

et al., 2003). However, contrary to what found analyzing superficial arthropod fauna and herpetofauna, QBS-ar index did not succeed in distinguishing areas with different management intensity. Indeed, we found no differences neither between the organically cultivated area in the experimental farm and the intensive managed field, nor between the habitat categories arable lands and meadows. This could imply that QBS-ar could be primarily affected by the vegetation cover features rather than by the management intensity of habitats. Indeed, arable lands, meadows and woody habitats are characterized by an increasing vegetation cover complexity. In general, our results support the efficacy of GAEC standard application for the enhancement of animal diversity in agricultural landscapes. The maps that we produced (Figure 7) shed light on the possible consequences of landscape uniformity on biodiversity in the surrounding of the study sites and highlight the particularly favorable situation recorded in the experimental farm. Such scenario suggests that the maintenance of the existing natural and semi natural habitats or the creation of new semi natural undisturbed areas, such as field margins, set aside areas and vegetation buffer strips, may indeed be a promising way for biological conservation in agricultural environments (Greaves and Marshall, 1987; Duelli and Obrist, 2003; Pfiffner and Luka, 2003; Bastian et al., 2007). These landscape elements contribute to create a certain level of environmental heterogeneity that, as seen, is important for the maintenance of species richness. A GIS application analogous to the proposed one could be used as a tool for the evaluation of the effectiveness of agricultural policies adopted in the context of rural development. Indeed such method, along with field studies aimed at assessing reference values, could be used to produce possible scenarios predicting the trend of biodiversity after the application of managing measures such as GAEC standards.

\section{References}

Andersen A.N., 1997. Densities of overwintering carabids and staphylinids. J. Appl. Entomol. 121:77-80.

André H.M., Ducarme X., Lebrun Ph., 2002. Soil biodiversity: myth, reality or conning? Oikos 96:3-24.

Andrén H., 1994. Effects of habitat fragmentation on birds and mammals in landscapes with different proportion of suitable habitat: a review. Oikos 71:355-366.

Asteraki,E.J., Hanks C.B., Clements R.O., 1995. The influence of different types of grassland field margin on carabid beetle (Coleoptera, Carabidae) communities. Agr. Ecosyst. Environ. 54:195-202.

Bastian 0., Corti C., Lebboroni M., 2007. Determining environmental minimum requirements for functions provided by agro-ecosystems. Agron. Sustain. Dev. 27:1-13.

Biaggini M., 2005. Diversità animale e agro-ambiente: analisi della fauna ad artropodi e "micro-vertebrati" e valutazione della qualità biologica del suolo in un centro sperimentale della Valdera. Degree Diss., Università degli Studi di Firenze, Italy.

Biaggini M., Dapporto L., Paggetti E., Corti C., 2006. Distribution of lacertid lizards in a Tuscan agro-ecosystem (Central Italy). pp 13-21 in: C. Corti, P. Lo Cascio and M. Biaggini (eds.), Mainland and Insular Lacertid Lizards: a Mediterranean Perspective. Firenze University Press, Italy.

Biaggini M., Consorti R., Dapporto L., Dellacasa M., Paggetti E., Corti C., 2007. The taxonomic level order as a possible tool for rapid assessment of Arthropod diversity in agricultural landscapes. Agr. Ecosyst. Environ. 122:183-191.

Biaggini M., Corti C., Nulchis V., Satta M.G., 2009. Azione 2: Acquisizione dati su Anfibi e Rettili come indicatori dei cambiamenti climatici. In: Supporto per la valutazione degli effetti climatici sulla biodiversità, raccolta di dati naturalistici e loro gestione. Final Report 2009, Ministero dell'Ambiente e della Tutela del Territorio e del Mare.

Blaustein A.R., Wake D.B., Sousa W.P., 1994. Amphibian declines: judging stability, persistence and susceptibility of populations to local and global extinctions. Conserv. Biol. 8:60-71.

Burel F., Baudry J., Butet A., Clergeau P., Delettre Y., Le Coeur D., Dubs F., Morvan N., Paillat G., Petit S., Thenail C., Brunel E., Lefeuvre J.C, 1998. Comparative biodiversity along a gradient of agricultural landscapes. Acta Oecol. 19:47-60.

Collinge S.K., 2000. Effects of grassland fragmentation on insect species loss, colonization, and movement patterns. Ecology 81:2211-2226.

Corti C., Lebborni M. Animal Diversity. In: 5th Framework Contract Ref: QLRT-1999-31666. Definition of a common European analytical framework for the development of local agri-environmental pro- 
grammes for biodiversity and landscape conservation. AEMBAC WP 14 Final Reports 2004.

D'Avino L., 2002. Esposizione del metodo di Vittorio Parisi per la valutazione della Qualità Biologica del Suolo (QBS) e proposta di standardizzazione delle procedure. CD R0M. Museo di Storia Naturale di Parma, Italy.

Duelli, P., Obrist, M.K., 2003. Regional biodiversity in an agricultural landscape: the contribution of semi-natural habitat islands. Basic Appl. Ecol. 4:129-138.

Gardi C., Jacomini C., Menta C., Parisi V., 2003. Evaluation of land use and crop management impacts on soil quality: application of QBS methods. Agricultural Impacts on Soil Erosion and Soil Biodiversity: Developing Indicators for Policy Analysis. pp 1-12 in Proc. from an OECD Expert Meet., Roma, Italy.

Germaine S.S., Wakeling B.F., 2001. Lizard species distributions and habitat occupation along an urban gradient in Tucson, Arizona, USA. Biol. Conserv. 97:229-237.

Gibbons J.W, Stangel P.W., 1999. Conserving amphibian and reptiles in the new millenium. Proc. the Partners in Amphibian and Reptile Conservation (PARC) Conf., Atlanta, GA, Aiken, SC, Savannah River Ecology Laboratory. Herp Outreach Publication, no 2.

Gibbons J.W., Scott D.E., Ryan T.J., Buhlmann K.A., Tuberville T.D., Metts B., Greene J.L., Mills T.M., Leiden Y.A., Poppy S.M., Winnw C.T., 2000. The global decline of reptiles, deja' vu amphibians. Biol. Sci. 50:653-666.

Graziani F., Berti R, Dapporto L., Corti C., 2006. Podarcis lizards in an agro-environment in Tuscany (Central Italy) : preliminary data on the role of olive tree plantations. pp 65-72 in: C. Corti, P. Lo Cascio and M. Biaggini (eds.) Mainland and Insular Lacertid Lizards: a Mediterranean Perspective. Firenze University Press, Italy.

Greaves M.P., Marshall E.J.P., 1987. Field margins: definitions and statistics. In: J.M.Way and P.W. Greig-Smith, Field margins. Proc. British Crop Protection Council, March 1986, London, UK, Monogr. 35:3-10.

Hodar J.A., Pleguzuelos J.M. Poveda J.C., 2000. Habitat selection of the common chameleon (Chamaleo chamaleon) (L.) in an area under development in southern Spain: implications for conservation. Biol. Conserv. 94:63-68.

Hunter M.D., 2002. Landscape structure, habitat fragmentation, and the ecology of insects. Agr. Forest Entomol. 4:159-166.

Kremen C., Colwell R.K., Erwin T.L., Murphy D.D., Noss R.F., Sanjayan M.A., 1993. Terrestrial arthropod assemblages: their use in conservation planning. Conserv. Biol 7:796-808.

Kromp B., Steinbeger K.L. ,1992. Grassy field margins and arthropod diversity: a case study on ground beetles and spiders in eastern Austria (Coleoptera: Carabidae; Arachnida: Aranea, Opiliones). Agr. Ecosyst. Environ. 40:71-93.

Kuussaari M., Hanski I., Singer M., 2000. Local speciation and landscape-level influence on host use in an herbivorous insect. Ecology 81:2177-2187.

La Mantia T., 1997. Il ruolo degli elementi diversificatori negli agroecosistemi mediterranei: valorizzazione e relazioni con le popolazioni di vertebrati. Naturalista Siciliano N.S.21/suppl.1:175-211.

Maisonneuve C., Rioux S., 2001. Importance of riparian habitats for small mammal and herpetofaunal communities in agricultural landscapes of southern Québec Agriculture. Ecosyst. Environ. 83:165-175.

McNeely J.A., 1995. How traditional agro-ecosystems can contribute to conserving biodiversity. In: P. Halladay and D.A. Gilmour (eds.)
Conserving Biodiversity Outside Protected Areas. IUCN Publ., Gland, Switzerland.

Meeus J., Wijermans M., Vroom M., 1990. Agricultural landscapes in Europe and their transformation. Landscape Urban Plan. 18:289352.

Moser D., Zechmeister H.G., Plutzar C., Sauberer N., Wrbka T., Grabherr G., 2002. Landscape patch shape complexity as an effective measure for plant species richness in rural landscapes. Landsc. Ecol. 17:657-669.

Nentwig W., 2003. Managment of biodicersity in agroecosystems. Basic Appl. Ecol. 4:135-136.

Paggetti E., Biaggini M., Corti C., Lebboroni M., Berti R., 2006. Amphibians and reptiles as indicators in Mediterranean agroecosystems: A preliminary study. pp 107-110 in: M. Vences, J. Köhler, T. Ziegler and W. Böhme (eds.) Herpetologia Bonnensis II. Proc. 13th Congress of the Societas Europea Herpetologica, Bonn, Germany.

Parisi V., 2001. La qualità biologica del suolo. Un metodo basato sui microartropodi. Acta Naturalia de L'Ateneo Parmense 37:97-106.

Parisi V., Menta C., Gardi C., Jacomini C., 2003. Evaluation of soil quality and biodiversity in Italy: the biological quality of soil index (QBS) approach. Agricultural Impacts on Soil Erosion and Soil Biodiversity: Developing Indicators for Policy Analysis. pp 1-12 in Proc. from an OECD Expert Meet., Roma, Italy.

Parisi V., Menta C., Gardi C., Jacomini C., Mozzanica E., 2005. Microarthropod communities as a tool to assess soil quality and biodiversità: a new approach in Italy. Agr. Ecosyst. Environ. 105:323-333.

Pfiffner L., Luka H., 2003. Effects of low-input farming systems on carabids and epigeal spiders-a paired farm approach. Basic Appl. Ecol. 4:117-127.

Phillipson J. ,1971. Methods of study in quantitative soil ecology: population, production and energy flow. HBP Handbook No. 18. Blackwell Publ., Oxford, UK.

Sacchi C.F., Testard P., 1971. Ecologie Animale. Doin Ed., Paris, France.

Shaffer M., 1997. Minimum viable: coping with uncertainty. pp 69-86 in: M.E. Soulé (ed.) Viable population for conservation. Cambridge University Press, Cambridge, UK.

Shannon C.E., Weaver W., 1948. The Mathematical Theory of Communication. University of Illinois Press, Urbana, IL, USA.

Smart R., Whiting M.J., Twine W., 2005. Lizards and landscape: integrating field surveys and interviews to asses the impact of human disturbance on lizard assemblages and select reptiles in a savanna in South Africa. Biol. Conserv. 122:22-31.

Wallwork J.A., 1976. The distribution and diversity of soil fauna. Academic Press London.

Wilcove D.S., McLellan C.H., Dobson A.P., 1986. Habitat fragmentation in the temperate zone. pp 237-255 in: M.E. Soulé (ed.) Conservation Biology: The Science of Scarcity and Diversity. Sinauer Associates Inc., Sunderland, MA, USA.

Wilson E.0.m 1988. Biodiversity. National Academy Press, Washington, DC, USA.

Woodcock B.A., Westbury D.B., Potts S.G., Harris S.J., Brown V.K., 2005. Establishing field margins to promote beetle conservation in arable farms. Agr. Ecosyst. Environ. 107:255-266.

Zechmeister H.G., Moser D., 2001. The influence of agricultural landuse intensity on bryophyte species richness. Biodiver. Conserv. 10:1609-1625. 